\title{
USING INTERACTIVE GAMES FOR THE TEACHING OF QUESTION TAGS: INSIGHTS FROM AN ENGLISH LANGUAGE COURSE IN INDONESIA
}

\author{
Meiva Eka Sri Sulistyawati ${ }^{a}$ \\ Universitas BSI Jakarta, meiva.mes@bsi.ac.id \\ Lady Diana Warpindyastuti ${ }^{b}$ \\ Universitas BSI Jakarta, lady.lwd@bsi.ac.id
}

\begin{abstract}
Learning a foreign language, being a part of our education system, has been taught from the early stage of education. However, there have been many barriers for learners to learn and for the teachers to make the learning more engaging and fun. This research aims to showcase how the deployment of interactive games can help students to better understand about questions tags and its use in the daily conversation. The study involved the Junior High School students participating in the English for All (EFA) English Language Course in Cirendeu, Tangerang Banten, Indonesia. Oral tests and activities were applied to garner the data regarding the improvement the students have made in understanding and using the questions tags.
\end{abstract}

Keywords: Question Tags, Interactive Games, EFA.

\section{INTRODUCTION}

Learning a foreign language, being a part of our education system, has been taught from the early stage of education. However, learning foreign language, especially English is not easy. Nowadays, the subject is not only introduced in Junior High School, but also already learnt in some kindergartens. It means that English has been introduced in the early stage of education. It can make the students familiar with English from their early ages.

Teaching is one of the important things in learning the foreign language. Teaching process is the facilitation of learning, in which the teachers can teach a foreign language successfully if they know the good methods that can be used in teaching and learning process. A good teacher as a facilitator in the class should be creative in creating the most effective and efficient way which can 
interest the learners to study English. In the end, the result of the study is the result of team work between the students and the teachers.

As one of the four basics English skills, it is very important for students to learn and to be able to understand grammar correctly. Grammar is not easy for the beginners, especially for those who never use English before. The writers find that from their teaching experiences in many years and many levels of education, teaching question tags is problematic. Many students find difficulties in understanding question tags. If they do not know how to use them especially, they will not be able to apply in daily use. In addition the writer feels that techniques of teaching question tags for children are not enough. That is why the writers want to teach question tags for children in this study.

The teacher usually uses a medium or a tool for teaching such as game. Games can make students happy and excited to study so they feel enjoy during the process of teaching. games help children to reduce stress during their studying. They make children funny, happy, interesting and comfortable when they are played games, which will help children concentrate on the lesson and learn better. Morever, children will remember English words according to games the most effectively. Games help children to interact with other members in the class. In fact, games create the opportunity for them to make friends with other members in the class. They become friendly and have a close-knit relationship. After playing games, they will learn experiences, share knowledge and exchange skills with their friends, which makes children learn well.

Moreover, games also help childen to enhance listening skill. For example,when the teacher gives rules of games in English. In fact, if the children don't focus on teacher's instructions they will not understand the rules and can not play the games. So, children have to concentrate on the teacher's instructions to understand what the teacher says and do as teacher guides, which helps children improve English listening skill.

Furthermore,when the children are played games they will have the chance to increase the cooperation. They will cooperate with your friends to try their best to win the games. In additon, At the end of game, the children have the opportunity to evaluate 


\section{Sulistyawati, M. E. S., \& Warpindyastuti, L. D., Using Interactive...}

other groups, which rises the cognitive ability of children. Moreover, games also help students to improve their listening skills. for example the teacher often use the target language to give the rules of games, which helps students to try to listen and understand what the teacher instructs.

Games are very useful for young learners, but to use games the most effectively the teacher should choose the games that are useful for children, Especially games must be related to the lesson and suitable with children. For example, Hangman- this is a great game to help children practice new words and spelling skills. This game is very good for the teacher to teach vocabularies for children. Games are very effective in teaching English for young learners. Being an English teacher it is very necessary for you to use games in teaching English for students.

This study aims to analyze the use of games in teaching question tags for Junior High School Students participating in an English language course in in Cirendeu, Tangerang Banten.

At the outset, it is important to understand the activities. Before teaching question tags using games for the seventh grade at English for All (EFA), the researchers will give explanation clearly on the definition forms of teaching, question tags and games. Then, the authors will continue to discuss class preparations before starting to teach their students. They are in preparation on lesson plan, exercises and preparation how to teach their students.

Then, it focuses on how to apply the games in the class to teach question tags and to make the students interested in this lesson. The games are bingo on the whiteboard, write as fast as you can and traffic light. The researchers must prepare the equipment of the games, such as whiteboard, marker, eraser and card. An eightmeeting field research in a month had been applied at the English For All (EFA) English Course. In first meeting there were six students coming to study. They were around twelve years old. The teacher taught Question tags using games and they were very interested in following the lesson in the classroom. 


\section{REVIEW OF RELATED LITERATURE \\ a. Definition of Teaching}

To transfer information the teacher has to know definition of teaching. There are some experts who had defined what is teaching.

According to Tomlinson (2001), "Language teaching is used to refer anything done by materials developers or the teacher is to facilitate the learning of the language," (p. 3). It means teaching is a facility in learning process of the language and teacher as facilitation.

According to Joyce and Weil (2007, p. 79), "Teaching is a process by which teacher and students create a shared environment including sets of values and beliefs (Agreement about what is important) which in to color their view of reality". Students come to school with different learning style, requiring different approaches to be followed to make for effective learning.

According to Wyse and Jones (2004, p. 2), "During the 1970 s and 1980s the teaching of language was the focus". So, in giving knowledges, teacher must concentrate in the materials of the subject and stay focus. It means in those years of age, teaching language was the most important subject for the teacher to teach teaching is process of transferring and understanding from the teacher to the pupil their students. Teaching language was the main purpose of teaching and all students had to learn it.

The writers conclude that teaching is facilitation in learning process. Teaching is activity which is performed, directly or indirectly by human being. Consequently, everyone who writes about it is a potential teacher or pupil and situation to show what the teachers explain to the pupils. Teaching is not only giving lesson to the students, but also how the teachers deliver the lesson to the students. Teaching can give the knowledge to the students and teaching can know the characteristic of the students.

\section{b. Principles of Teaching Young Children}

According to Joseph \& Strain, (2002, p. 4), "For emotional vocabulary teaching to be effective adults must first spend the time necessary to build positive relationships with children". It means that is foundational context of a warm and responsive relationship 


\section{Sulistyawati, M. E. S., \& Warpindyastuti, L. D., Using Interactive...}

with children, teachers can maximize their influence to enhance emotional vocabulary".

According to Denham, (1986, p. 4), "Classrooms that devote planned attention to help children acquire a rich and varied feeling vocabulary we may expect fewer challenging behaviors and more developmentally sophisticated and enjoyable peer social." It means that to help the children become smart and enjoyable.

According to Mc Closkey (2002, p. 67), "An effective teaching of young learners promotes innate language acquisition mechanisms by providing children opportunities to use language as a tool for creating and sharing meanings and by scaffolding experiences to help children function. Effective teaching, therefore, involves authentic communication between learner and teacher and among learners, and is activity-based, providing purposeful ways for students to use language to meet appropriate goals". It means that using language goals from one age group for learners at earlier ages may not serve any benefit, but instead may cause learners to miss important opportunities. There are seven instructional principles of teaching young teachers:

1. Offer learners enjoyable, active roles in the learning experience.

Young learners are meaning-seekers who learn best by doing and who prefer a safe, but still challenging learning environment. Direct instruction methodologies and content intended for older learners are being pushed down to classes of younger learners based on the idea that introducing them sooner will make learning more effective. But young children learn differently and need different learning environments. Overuse of direct teaching of young learners in the full classroom group risks the fallacy that "input" will automatically lead to "intake" that if we teach something, it has been learned. But for young children, active involvement in the construction of concepts is essential. We must provide input in child appropriate ways and offer many opportunities for children to use language purposefully as language develops. For example, once we have modeled language and procedures for water experiments about things that float and things that sink, or which container holds more water, we can provide opportunities on the playground for children to experiment with 
water and use the language in discussions. By asking questions and making comments as children participate in their very purposeful play and learning tasks.

2. Help students develop and practice language through collaboration.

Children are social learners. While ensuring that students have access to vocabulary and structures they need and rich exposure too many kinds of literature is a very effective way to model high quality, academic language and then supporting their language as needed, we provide opportunities for learners to communicate with us and with one another. During the water explorations, for example, one child could be encouraged to conduct the experiments while others give instructions and ask questions about what they see happening.

3. Use multi-dimensional, thematically organized activities.

Provide thematically organized activities and incorporate multiple dimensions of learning and learning styles appropriate to younger learners. Thematic organization offers us opportunities to cycle and recycle related language and concepts so that we can support children as they develop the complex connections that lead to learning. We need to incorporate many kinds of childdevelopment appropriate activities into children's exploration of themes: we might move like waves on the sea, sing songs about sailing on the ocean, draw pictures of our experiments or our favorite water creatures, weigh and measure water, solve problems about sharing lemonade, read and reflect on a story about a mother duck temporarily losing one of her little ones, and, with children, write reports about what we are learning and thinking about.

4. Provide comprehensible input with scaffolding.

Provide rich yet comprehensible input with supportive scaffolding from teacher, context, and peers to help learners work at the ZPD or "the growing edge" providing tasks and concepts that the children can accomplish or acquire with just a little instruction and support. When children can perform these tasks independently, the growing edge changes or expands, and teachers then support learners with slightly more difficult tasks and concepts. Since teachers must continually focus on providing input and requests for output that children will need to perform at the 


\section{Sulistyawati, M. E. S., \& Warpindyastuti, L. D., Using Interactive...}

next level, they must use careful observation and classroom-based assessment to know their children's capabilities well. Scaffolding activities for reading and writing might include reading a story aloud, providing graphic organizers to help children understand and discuss the language patterns and structure of a story, and shared writing with children from the graphic organizer. Integrate language with content.

Teaching language for age-appropriate academic content has several advantages: Students learning two languages in school in a bilingual setting curriculum can be integrated across languages, so that the children in L2 (second-language) classrooms encounter the same concepts that they do in L1 (first language) classrooms but with new labels, both reinforcing the content-area learning and facilitating the new language learning because it is based on what children already know. In a L2 setting, teaching language through content means that students' academic learning is not delayed while they learn language. Rather, they have the opportunity to learn language in age-appropriate, stage appropriate activities that will prepare them for grade-level academic content.

5. Validate and integrate home language and culture.

Continued development of children's home language will only support development of a new language. Another misunderstanding of how language develops that is common outside linguistic and language educational circle is that a first language can hinder or interfere with a second. Rather, students with good academic learning in their first language are clearly at an advantage when they begin to learn additional languages. When a child "breaks the code" or "joins the literacy club" and understands the basic concepts of reading in one language, this does not need to be re-learned in the target language. Rather, students now need to learn only new words, new sounds, and new written codes - no small task, but a much easier one than learning to read in a new language when a child doesn't have literacy concepts. As language educators, we can help young learners use their knowledge and learning experiences of their home language to expand their learning in a second language. Acquiring a new language should clearly be an additive process and should never necessitate losing one's mother tongue. 
6. Provide clear goals and feedback on performance.

Children want to do right. They need to know when they've achieved a goal and when they still have more to learn. We must establish clear language and content goals for learners and provide learners with feedback on their progress toward those goals. We can also, in developmentally appropriate ways, encourage learners to begin to evaluate their own progress toward accomplishing goals to help them become independent, self-motivated learners.

The teacher must devote as much individual attention as possible to teach children. An important process of learning is encouraging and commending the children for their efforts.

\section{Definition of Question Tags}

According to Huddleston and Pullum opinion (2002, p. 934) in their book, which is stated as "A tag question is formed with shall we? Or will we? (instead of will you? or won't you?), and negation can be formed either with do not/don't or just with not without changing the semantic scope". It means that Question tags positive the answer must be negative.

According to Raymond (2002, p. 104), "questions tags is mini questions which we put on the end of a sentence". It means that in questions tags use the auxiliary verb, for the present, past and future. Use do/does/did/was/were/have/has/had/shall.

According to Wren \& Martin (2003, p. 305), "Question tag is a common practice in conversation to make a statement and ask for confirmation". The example of which can be seen in the table 1 and 2:

Table 1. Sample of Question tags with positive statement

\begin{tabular}{ll}
\hline \multicolumn{1}{c}{ Positive sentence } & negative tag \\
\hline It's very hot, & isn't it? \\
Ann will be here soon, & won't she? \\
Tom should pass his exam, & shouldn't he? \\
They Came by car, & didn't they? \\
\hline
\end{tabular}

Table 2. Sample of Question tags with Negative statement

\begin{tabular}{ll}
\hline Negative sentence & Positive tag \\
\hline Tom won't be late, & Will he? \\
They don't like us, & Do they?
\end{tabular}




\section{Sulistyawati, M. E. S., \& Warpindyastuti, L. D., Using Interactive...}

That isn't George over here You haven't seen Ann today, Is it? You couldn't do me a favour, Have you? Could you?

The writer concludes that question tags is mini questions which put on the end of a sentence and ask for confirmation. questions tags is not only giving question to the student. But also how the teacher delivers the question to the student. Actually, question Tags use for short question but easy to learn.

\section{c. Definition of Games}

According to Hadfield (1998, p. 4), "A game is an activity with rules, a goal and element of fun". It means that games are a vital part of a teacher's equipment, not only for language practice they provide, but also for the therapeutic effect they have. They can be used at any stage of a class to provide an amusing and challenging respite from other classroom activity and are especially useful at the end of during the day to send students away feeling cheerful about their English class. Games can be the media to teach young learners for some reasons.

According to Wright et al (1997, p. 1), "Games can be found to give practice in all the skills (reading, writing, listening, and speaking), and for many types of communications (e.g. encouraging, criticizing, agreeing, explaining)". Games are used to make the children easier to understand and remember vocabularies in some topics. By using games, the children do not feel that they learn something through that activity. Through games the students become active learners. The teacher should have a creative way in giving the materials to the students that one of the ways is by doing some fun activities.

According to Linse (2001, p. 5) explains that "The games for the most part are variations of favorite childhood games play purely for recreational purposes". It mean that games have many variations that make students interesting so the teacher can reach the purpose of teaching through creating a new game that relevant with the subject.

According to Shaptoshvili (2002, p. 34), "Games are important parts of a teacher's repertoire. Although they are 
recreational activities by nature whose main purpose is having enjoyment in learning English. In language learning process their purpose is to rein force what has already been thought". It means that although the game is fun, but in the language learning it is more difficult because the problem is suitable with the language.

Games have a great educational value and it can be used in the classroom to make learners use the language instead of just thinking about learning the correct forms. Games encourage learners to interact, cooperate, to be creative and spontaneous in using the language in a meaningful way. Learners want to take part in activities; to play games and are generally quite competitive. In order for them to take part they must be able to understand and communicate in the target language. Games also encourage learners to keep interested in the work and a teacher can use them to create contexts in which the language is useful.

Games are used as methods or techniques to involve students in learning. Well-chosen and designed games are invaluable as they give students a break and at the same time allow learners to practise language skills. The benefits of games range from cognitive aspect of language learning to more co-operative group dynamics and as a result games are highly motivating since they are amusing and at the same time challenging. Ersoz (2000) states that games can be used to give practice in all language skills and they can be used to practice many types of communication.

Huyen (2003) identifies the advantages of using games to learn vocabulary in the classroom: a) Games add relaxation and fun, so the learners retain words more easily. b) Games involve friendly competition, so it keeps learners interested and motivated. c) Vocabulary games bring real world context to the classroom. Mei (2000) emphasizes similar points by saying that it encourages active learning, as well as collaboration and interactivity. Interactive learning techniques also hold memory, performance and social benefits. According to I-Jung (2005) the benefits of using games in language-learning include that games are learner centered, encourages creative and spontaneous use of language and foster participatory attitudes of the learners.

Kim (1995) states more general advantages of using games in the classroom and they include: 


\section{Sulistyawati, M. E. S., \& Warpindyastuti, L. D., Using Interactive...}

1. Games are a welcome break from the usual routine of the language class.

2. They are motivating and challenging.

3. Learning a language requires a great deal of effort. Games help students to make and sustain the effort of learning.

4. Games provide language practice in the various skillsspeaking, writing, listening and reading.

5. They encourage students to interact and communicate.

6. They create a meaningful context for language use.

Students learn through experimenting, discovering and interacting with their environment. Students need variation to increase their motivation. By using games students already have a context in which the use of the target language is immediately useful. This learning situation is similar to how mother tongue speakers would learn without being aware they are studying.

- A game must be more than just fun.

- A game should involve "friendly" competition.

- A game should keep all of the students involved and interested.

- A game should encourage students to focus on the use of language rather than on the language itself.

- A game should give students a chance to learn, practice, or review specific language material.

According to Gaudart (1999), there are four types of games that can be used and they are: card games, board games, simulation games, and party-type games. When choosing games a teacher does not have to have a multitude of games up his/her sleeve, but rather creativity at taking existing, familiar or popular games and adapting it to the classroom to aim for maximum student involvement. Traditional games like hangman, Pictionary, charades, Chinese Whisper, Bingo, Snakes and Ladders, Battleships, Who wants to be a millionaire? etc. can be modified and tailor-made for your learners and teaching content. Many games require modification in use when the students' needsare taken into consideration. It is also important to note that a game doesn't need to involve a lot of movement or excitement or cheering, but it does need to be intellectually challenging.

Teachers can use a variety of extra incentives to keep the 
energy in the classroom going during games with: group or team competition, using small prizes depending on age (stickers, stamps, reward points etc), using dice to determine amount of points or using fake money or playing cards as point system (every time a student answers correctly he/she receives a card or note). Students could be given a sticky ball to throw at vocabulary words, grammar structures etc that are written on the board and then asked to use them in sentences. Or alternatively they could answer a question and throw at a target on the board to win points. A paper airplane or bean bag could also be used in a similar way. Small whiteboards can be used in spelling competitions and be sent around in the team. Students love to play rock-paper-scissor and it can be adapted for various functions within games.

Games could also be based on real-life sport such as baseball or basketball. The teacher can draw a playing field/court on the board and each time a student/team answers a question they can move to the next base or score a goal. Interactive games such as hot seating or role play can also be used. Teams can, for example, do "shopping", where they have to buy a certain amount of things with their money, while at the same time practising dialogues and vocabulary. Another popular game is Taboo; where a student from each team sits with their back to the board, the teacher writes a word on the board and the rest of the team must explain the word without using/saying it. The first team to guess the word correctly wins. A similar game that can be adapted for the classroom is 30 Seconds. An ABC game can also be used where students have to give a word beginning with the next letter of the alphabet. Or a similar game is Chain spelling, where a student is asked to spell a word and then the next student must say and spell a word beginning with the last letter of the previous word. With newly arrived students teachers can use a school or campus treasure hunt.

Teachers can use Directed Activities Related to Texts (DARTs) such as jigsaws, prediction, sequencing etc in a competitive way to create a game. For example the first team to assemble their jigsaw wins; the team to make the closest prediction wins; the team who correctly sequences events/storyline wins. The teacher can then use DARTs to present or practice the target 


\section{Sulistyawati, M. E. S., \& Warpindyastuti, L. D., Using Interactive...}

language, yet at the same time it can develop into a game. There are innumerable ideas for games available, but the success of the games depends on the teacher. The teacher must ensure that the games are appropriate for their students and that it is relevant to their work or real-life.

Games can definitely be used for all age groups, but some caution is needed when used for adult learners. Teachers have to ensure that their games are age appropriate and not too easy or challenging for their students. Kopecky (2009) states that adult students look for structure in lessons and by keeping a game clearly tied to the work it helps maintain their confidence in the teacher. He advises that you should know your adult students (their interest, how they interact etc) and prepare games that are intellectually challenging and have some "substance". Ensure that clear instructions are given and that students clearly understand the goal of the game. To motivate adult students you have to be motivated and enthusiastic yourself, yet professional when executing the game. Ensure that you monitor as the students play the game to help them keep the goal of the activity in mind and also monitor your time.

Hong (2002) suggests a few questions to keep in mind when considering which game to choose for the different age groups: Which language does the game target? Which skills does it practice? What type of game is it? What's the purpose for using it? Does it fit the students? How could I simplify or make it more complex if necessary? How much interaction and participation is there? Do I like the game myself?

Important things to consider when using games in the classroom

- Choose suitable games (depending on the number of students, proficiency level, cultural context, timing, learning topic, and the classroom settings).

- The way students perceive a game depends on the actual design and implementation of the game.

- Give clear instructions, give clear rules and give clear time limits.

- Rather demonstrate than explain.

- There must be a clear purpose and achievable goals.

- Clear objectives and goals must match the difficulty level of 
the game and ability level of the students.

- Ensure that shy or quiet students are not alienated and have an opportunity to take part.

- Debriefing, or the evaluation of results/ events in the game, is crucial to the game's success.

- It must still be fun, but still help the students to learn.

Games lower anxiety levels, are entertaining, educational and give students reason to use the target language. It is a natural way of learning and exposes students to real learning opportunities. "Games encourage, entertain, teach, and promote fluency. If not for any of these reasons, they should be used just because they help students see beauty in a foreign language and not just problems that at times seem overwhelming (Uberman, 1998).

The writer concludes that games for children is facilitation and practice on one way in learning process which playing something by doing some fun activities. Games are using to make the children easier to understand and remember the lesson in some topics. Teaching question tags using games to the children can become active learners.

\section{DISCUSSION}

In this section, the research presents the instructional activities. Before the teacher teaches the students, the teacher should prepare a lesson plan, so that the teaching and learning process in the class can become active, creative, effective and fun. The instruction in the class can be organized and can be engaging.

\section{a. Teaching Preparation Activities}

In pre-teaching the teachers must be prepare themselves before start the activity of teaching and learning process happens. The writers have to give more time for the students to learn themselves before begin to study the lesson so when the study begin, they feel more comfortable. Because they still like playing and have fun. The teachers called of the student name one by one, the function of the attendance list to check the students who attends the class every day. After that to make the students more comfortable like the teacher asking the condition of the students like "Hi students, how are you today? " or the teachers can asking about their holiday last week. In the beginning the teacher can 


\section{Sulistyawati, M. E. S., \& Warpindyastuti, L. D., Using Interactive...}

start with greeting then continue with the check attendance list before begin the lesson. With a lesson plane, we hope learning process in the class can active, creative, effective and fun. So the main important point can be achieved. The following are contents about pre teaching that must the teachers make. They are:

1. Basic competence: It means capability in learning that must be owned the students.

2. Indicator: It means characteristic, identify, attitude that must do or the students show.

3. Material lesson: It is point will be learned the students in every unit lesson.

4. Lesson Activity Method: It means what methods that the teachers use to teaching in the class whether demonstration, asking question, picture, etc.

The teachers taught Question Tags the order may of the teaching preparation varied from one unit to the next, but the specific stages of the preparation phase are:

1. Making Lesson Plan

The teacher makes preparation of teaching depends on the lesson that the teacher was going to teach. This plan includes a statement of lesson objective, the procedures and facilities to be used during the lesson, the specific goals to be attained, the means to be used for reviews and evaluation. For further explanation about lesson plan form has enclosure on appendices

\begin{tabular}{|l|l|}
\hline Aim & To practise tag questions. \\
\hline $\begin{array}{l}\text { Activit } \\
\mathbf{y}\end{array}$ & $\begin{array}{l}\text { Students choose the correct tag questions to } \\
\text { complete sentences. }\end{array}$ \\
\hline $\begin{array}{l}\text { Organi } \\
\text { sation }\end{array}$ & Individual / pair work \\
\hline $\begin{array}{l}\text { Prepar } \\
\text { ation }\end{array}$ & $\begin{array}{l}\text { Make enough copies of the worksheet for the } \\
\text { number of students in your class. }\end{array}$ \\
\hline
\end{tabular}




\begin{tabular}{|c|c|}
\hline $\begin{array}{l}\text { What } \\
\text { do I } \\
\text { do? }\end{array}$ & $\begin{array}{l}\text { 1. Cut up and mix the words before your lesson. } \\
\text { 2. Ask students to match the sentences and tag } \\
\text { questions. } \\
\text { 3. Turn all of the cards face down and play a } \\
\text { memory game: The first student turns over } 2 \\
\text { cards. If they match, the student keeps the pair } \\
\text { and tries again. If not, play passes to the next } \\
\text { student. The student with the most pairs at the } \\
\text { end is the winner. } \\
\text { You like fish | don't you ? } \\
\text { He isn't happy | is he ? } \\
\text { They aren't here | are they ? } \\
\text { He didn't eat anything | did he? We come } \\
\text { on Friday | don't we isn't it is she? } \\
\text { It's closed i isn't here today | is she } \\
\text { She is } \\
\text { They live in England | don't they? }\end{array}$ \\
\hline
\end{tabular}

2. The Book/Handbook and Other Books

The teacher often uses module or handbook; there were kind of books such as module for students and for the teacher. Then, the teachers take some books to teach in the class, which can help the material. They often use module or handbook; there are kind of books such as: module for students and for the teachers.

\section{Teaching Procedure}

The first meeting started. The teacher came to class at $3 \mathrm{pm}$, she will say greeting good afternoon because this is the first time so the teacher must introduce herself. She said her name, address, education, favorite food and drink. Then she gave a chance to students to ask, because the students' did not ask anything, the teacher continued the lesson. The students just listened to their teacher without asking anything. For greeting and introduction the teacher had 5 minutes. After introduction stage, the teacher took the attendance list and mentioned each name of the students in the classroom. After that, the teacher had 10 minutes to ask students and the students have to answer the question. 
Sulistyawati, M. E. S., \& Warpindyastuti, L. D., Using

Interactive...

\section{Greeting Stage}

Teachers: "Ok, let's start to the next lesson".

Students: "Ok, what is it?"

Teachers: "This lesson is about Question Tag"

Teachers: "Well, in Question Tag has an auxiliary verb, do you know about it?"

Students: "Yes, Auxiliary"

Teachers: "So, What they are?"

Students: "There are is, am, are, was, were, have, has, had, do, did, does, will, shall, would ..."

Teachers: "That's right. Now, we study about question tags. Question tag is a type of question which is added at the end of a sentence, and question tags have 2 types of sentence. So can you give one example sentence question tags?"

Students: "Are you a student, aren't I?"

Teachers: "Excellent. So, question tags........." (Their lesson is begun). The teacher had 10 minutes to ask students.

\section{Presentation Stage}

The teacher explained the lesson clearly and the students have to listen to the explanation and the instruction carefully. The teacher spent 10 minutes to explain the material of question tags to the students and the students have to memorize. The meaning of question tag is to make sure the information is correct or to seek agreement. A tag question is a question which is added at the end of a sentence. There is a fixed pattern which is said that if the sentence is positive the tag must be negative statement and if the sentence is negative the tag must be positive statement. The patterns of question tags are:

\section{Auxiliary Verb of Question Tags}

Look at these examples with positive statements:

\begin{tabular}{|c|c|}
\hline positive statement $[+]$ & negative tag $[-]$ \\
\hline Auxiliary & $\begin{array}{l}\text { personal } \\
\text { pronoun } \\
\text { (same as subject) }\end{array}$ \\
\hline
\end{tabular}




$\begin{array}{lll}\text { You } & \text { Are } & \text { Aren't you? } \\ \text { She } & \text { Does } & \text { Doesn't she? } \\ \text { You } & \text { Did } & \text { Didn't you? } \\ \text { They } & \text { Will } & \text { Won't they? } \\ \text { I } & \text { Can } & \text { Can't I? } \\ \text { We } & \text { Must } & \text { Mustn't we? } \\ \text { He } & \text { Should } & \text { Shouldn't he? }\end{array}$

Example:

1. You are going to school now, aren't you?

2. She likes to eat banana every morning, doesn't she?

3. You went to Pondok Indah Mall yesterday, didn't you?

4. I can ride a bicycle, can't I?

5. We must sing this song, mustn't we?

6. He should watch this movie, shouldn't he?

Look at these examples with negative statements:

negative statement positive tag $[+]$

[-]

$\begin{array}{lll}\text { Subject } & \text { Auxiliary } & \begin{array}{l}\text { Personal } \\ \text { Pronoun (same as } \\ \text { subject) }\end{array} \\ \text { It } & \text { Isn't } & \text { Is it? } \\ \text { He } & \text { Hasn't } & \text { Has he? } \\ \text { You } & \text { Don't } & \text { Do you? } \\ \text { I } & \text { Wasn't } & \text { Was I? } \\ \text { They } & \text { Weren't } & \text { Were they? }\end{array}$




\section{Sulistyawati, M. E. S., \& Warpindyastuti, L. D., Using \\ Interactive...}

Example:

1. He's read this book, hasn't he?

2. He read this book, didn't he?

3. He's reading this book, isn't he?

4. He reads a lot of books, doesn't he?

5. He'll read this book, won't he?

6. He should read this book, shouldn't he?

7. He can read this book, can't he?

\section{Exercise Stage}

After the teachers introduce the topic, the teacher divided the students become group and there are two groups. The teacher usually play bingo, traffic light, shoot the target with tag endings. In this meeting the teacher give students cards like with different tag endings (for example ..., have they?, haven't they?, doesn't she? does she?, don't you?, did you?, didn't you?, has he?, hasn't he?, was she?, wasn't she?, weren't we?, were we? Aren't they?, are they?, must we?, mustn't we?). Then the teacher take a card and read the sentence (She went to the supermarket yesterday) which group answered the first and true they will get point for their group and so long until the time of play the game has finished and which groups get many point they will be the winner. The game has taken 15 minutes. If they have a possible ending, they cross it out. The idea is to complete the card first. Students enjoy the game a lot! They have to pay attention to the tense and pronoun used.

\section{Games}

Game is one of things that make the students are more fun and not feel boring. The teacher has to create a game that related to the lesson. The games that the writer used in teaching question tags were:

1. Write as fast as you can and compete with their friends.

Firstly, the teachers explained the rules of those games and after that she asked the students to play the games based on the teacher's rule. It was done to make the students to be more active and to make them enjoy in doing the task. The teachers divided the students become two groups and they said to the students to stand up in the front of the class. After that the teacher said the students 
to make a sentence by using their own word and they must write down the sentence with the right answer on the whiteboard andwhose group can answer the question corretcly and the fastest they group will be the winner.

1. Bingo on the whiteboard

\begin{tabular}{|l|l|l|}
\hline $\mathrm{X}$ & & $\mathrm{O}$ \\
\hline & $\mathrm{X}$ & $\mathrm{O}$ \\
\hline & & $\mathrm{X}$ \\
\hline
\end{tabular}

Tables III.1 Bingo on the whiteboard

Teacher said to the student how to play this game. After that the teacher divided the students became two group. Then, the teachers draw the box on the whiteboard. A picture of game bingo on the whiteboard was hanging on the wall. Playing this game, the teacher found that the student will be more interesting and more understanding about the lesson question tags, understand the basic concepts of positive and negative statements as well as identify the subject and its pronoun form. So before the teacher began the lesson on question tags, she has to introduce and review these concepts with the students first. Those can be done in the form of a game where the children learn points if they are successful in completing the question tag. Oral practice also allows children to practice the rising intonation that is required in questions tags.

In playing this game, the teacher found that the student will be more interesting and more understand about the lesson question tags, understand the basic concepts of positive and negative statements as well as identify the subject and its pronoun form. So before the teacher begin the lesson on question tags, she has to introduce and review these concepts with the students first. This can be done in the form of a game where the children learn points if they are successful in completing the question tag. Oral practice also allows children to practice the rising intonation that is required in questions tags."

The game is over and there is have 30 minutes to do' their exercise and last the teacher give the students to did their exercise 


\section{Sulistyawati, M. E. S., \& Warpindyastuti, L. D., Using Interactive...}

in their workbook (the exercise in the appendices). While the students did their exercise the teacher went to check up around the paper of the students and the teacher sign and give score. The exercises were:

\section{Exercise I}

Fill in the blanks by using the correct question tags.

1. Mr Guinness is from Ireland

2. The car isn't in the garage, ?

3. You are John,

4. She went to the library yesterday,

5. The trip is very expensive,

6. He won't tell her,

7. You're Australian,

8. You aren't English,

9. Marlene smokes,

10. Sharks don't like chicken,

\section{Exercise II}

\section{Fill in the blanks by using the correct question tags.}

1. She is pretty,

2. He is handsome,

3. He often goes there,

4. They have a new car,

5. They slept last night

6. You should meet her,

7. He was there, ? $?$ ?

8. They were sleeping,_?

9. Sit down,

10. Get out,

11. I am right,

12. Do not touch me,

13. Open the door,

14. You are from Australia,

15. Let's go to the cinema,

They should make it into one choice form which had an answered. Before the teachers give them some exercises, the 
teacher would review the lesson that had been learnt. The teacher would ask the student, how to use question tag, kinds and meaning. The teacher would give one example on how to do the exercise. Then, the students started doing the exercises. They were doing diligently and quickly. They are very confused but they never give up doing their exercises. However, they could study English and do the exercises very quickly. It means that, the students were interested in English and accepted the lesson better. The teacher used fifteen minutes for answering the questions. After that, the questions would be discussed together. Then the teachers choose one the student for answer the question number one, the student gave right answer, but the second student gave wrong answer and the another student try to help their friend for answer of the question. It means that they have felt to help other students then they have fully spirit and never give up. These activities continued till all the questions done answered.

\section{Answer the snake and ladder quickly in fifteen minutes!}

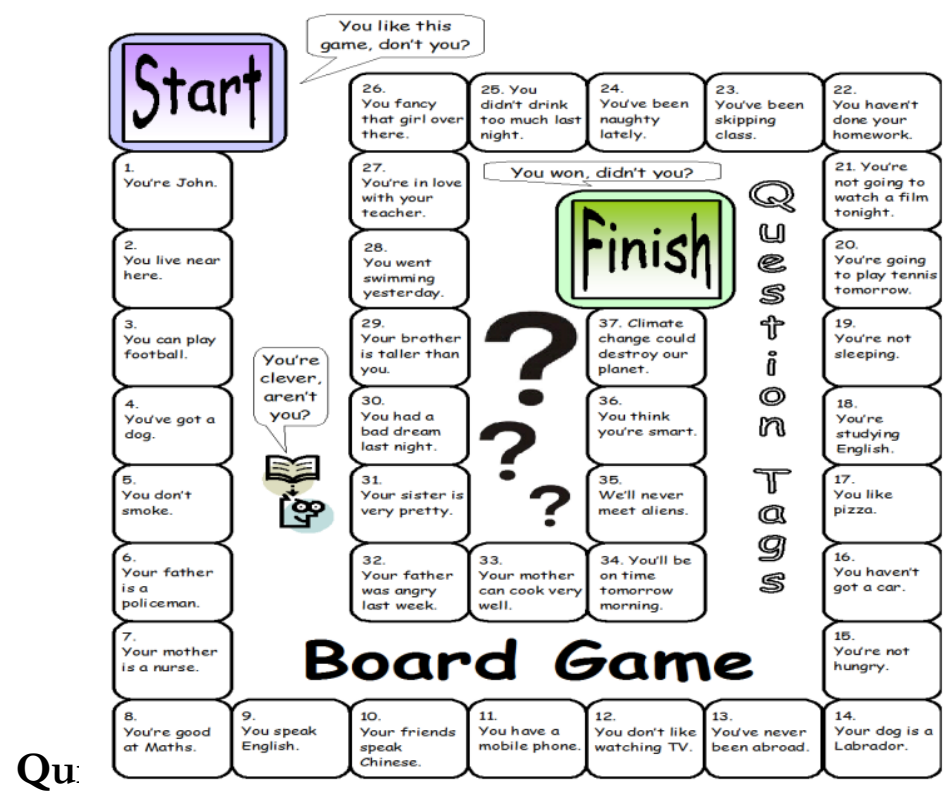

See if you can finish the following sentences with the correct question tag. The first ones are relatively easy, but then they get more difficult!

- You don't like me, ......?

- It isn't raining, ... ...? 
Interactive...

- You've done your homework, ......?

- I'm not late, ......?

- I'm invited to your party, ......?

- You like German food, ... ...?

- You'll come to my party, ......?

- You remembered to feed the cat, ......?

- Let's play tennis, ......?

- There's a problem here, ......?

- He never says a word, ......?

- Nobody came to your party, ......?

- Don't forget, ......?

- You think you're clever, ... ...?

- So you think you're clever, ......?

\section{Answers}

- You don't like me, do you?

- It isn't raining, is it?

- You've done your homework, haven't you?

- I'm not late, am I?

- I'm invited to your party, aren't I?

- You like German food, don't you?

- You'll come to my party, won't you?

- You remembered to feed the cat, didn't you?

- Let's play tennis, shall we?

- There's a problem here, isn't there?

- He never says a word, does he?

- Nobody came to your party, did they?

- Don't forget, will you?

- You think you're clever, don't you?

- So you think you're clever, do you?

\section{Closing}

When the students finished their exercises, these exercises were corrected together. All questions would be answered together or written on the blackboard. From these exercises the writer gave a score. This score showed the ability of the students that they could understand the material or whether they were interested in 
the English lesson or not. Then, after 30 minutes, the teacher sign and give score. And the time is up, the students have to come back home and the teachers said see you later.

\section{Teaching Analysis}

In this part, the teachers must analyze about Teaching English question tags English question tags using games. When the teachers taught the question tags using games, the students more interested to learn question tags because they can look the true pattern and the students more excited to answer question tags. In the first meeting, the teachers have to give some greetings. First, the children have to make some friendly greetings before starting the lesson. After that the teacher explains the lesson clearly, so the students can be more interesting and understanding about the lesson. The teachers also practice with the games because it can made the students easier to answer some of the questions from the teacher. Not only the teacher who practiced it but also asked the students to come forward and the teacher asked the students to practice about question tags to their friend, and the other students answer the question. When the students tried to practice in front of the class, they were very excited and happy. It has improved the children because first they don't understand about the lesson but after the teachers explained that they can understand and they got nice score.

So, the teachers taught many influences to the students if the teacher teaches question tags using games. The students were not bored and the students always happy because the students can practice in front of the class, and they feel proud because they can be the best. And also the students can be more active if they can practice then it can made the students more confident if they practice.

One of the biggest challenges in teaching the children are they are not behaviorally developed. The teacher found may be the first time some children have a significant body of rules to follow. In fact, learning how to follow rules and peacefully interact with peers are some of the primary reasons children attend to study. The solution is before deciding to teach question tags, determine if you have the ability to not only to enforce behavioral rules but also to 


\section{Sulistyawati, M. E. S., \& Warpindyastuti, L. D., Using Interactive...}

handle the stress and disorder that accompanies students' behavioral problems.

The solution is the teachers should give games in every meeting so that they were not boring and paid attention to the teachers. Games will help the students for thinking that English is very fun and they would like with English lesson, the teacher should arrange the seat formation in semicircle in order to make easy with the students, sometimes they always made some problems. The solutions mentioned above probably not only help to handle the difficulties and problems that influence teaching process in the classroom, but also they are expected to minimize the problems. These solutions are useful for teachers to be applied in the classroom when they face the problem in teaching and learning process.

\section{Teaching Evaluation}

In teaching evaluation the teachers found the difficulties in teaching were on how the teachers gave it slowly, using English some student could accept the lesson. The conditions of the class were very quiet. The students did listen while the teacher explained the lesson. They have many kinds of students character in the classroom.

Some students were not afraid of the teachers, they sometimes did not pay attention. Some students pay attentions while the teachers were explaining the lesson, they could understand fully. In this situation, the students would be given a chance to ask but some body still asked the teacher. The students who never gave attention, they were confused. While the writers they were cheating task their friends and the other students making noisy with each other their friends though suddenly they were laughing together.

\section{Purpose and Problem and Solution}

Based on the analysis, the teachers conclude teaching question tags using games can get many advantages, the students more active because the teachers always asks the students to practice and the can't feel bored when the students learn question tags. And also the students will more interest because they can look the pattern of 
question tags, it can make they excited to learn question tags. And also, the teachers think teaching question tags using games is very suitable to teach sixth grade because it can make the teacher easy to teach question tags and it can simpler to teach question tags. The first advantage of applying some games in teaching learning process was the students could be more interested in learning the material. When the students were interested in learning the material, they would give more attention to the lesson given. That condition gave a good chance for both the teacher and the students. On the occasion the teacher could deliver the material very well and the students could understand what they had learned on that day.

The second advantage of applying some games in teaching learning process was the teacher didn't need to explain too many materials. The teacher just explained the materials needed by the students because they can understand the material on that day by doing the games. The games could give the students more change to understand the material given because through playing they can learned something without realized that.

\section{The disadvantages:}

The first disadvantage of applying games in teaching learning process was by attracting student's interest to games, all of them were active and made noisy. Sometimes they too much moved and spoke. That condition made the teacher difficult to control them.

The second disadvantage of applying some games in teaching learning process was by doing games the teacher only had a little time to explain the material and gave some sentences of question tags.

From all the explanation above, it shows that using games to teach is good technique especially by applying the creative activity one but there were also some disadvantages in using games in teaching question tags to the young learners especially for the sixth grade students in Butterfly English Course.

\section{Problem and solution of Greeting}

The problem in teaching the children at such a young age is they 


\section{Sulistyawati, M. E. S., \& Warpindyastuti, L. D., Using Interactive...}

are not behaviorally developed. The teacher found may be the first time some children have a significant body of rules to follow. In fact, learning how to follow rules and peacefully interact with peers are some of the primary reasons children attend to study.

The solution is before deciding to teach question tags, determine if you have the ability to not only to enforce behavioral rules but also to handle the stress and disorder that accompanies students' behavioral problems.

\section{Problem and solution of study stage and active stage}

In teaching learning process, the teacher found some problems. The first problem is on how to make the students understand about the material. In this class, only 70 percent of students could accept the lesson because the students are less attention for their teacher. The students were very busy with their activities, examples while the teacher was explaining the lesson. One of the students who did not give attention suddenly, the teacher could give question related the lesson. In delivering the lesson the teacher found some students who did not pay attention to the lesson.

Second the teacher prepared the things of game such as card, ball, and equipment of game. Before the teachers teach in the classroom, first the teacher has to study how to play that game. The teacher has to choose the suitable games to teach question tags. The students who never gave attention, they were confused. While the writers that they were cheating task their friends and the other students making noisy with each other their friends though suddenly they were laughing together.

The students pay attentions while the teachers explained the lesson. But some of them did not still understand yet, the teachers would explain again slowly and explain one by one. Situation of the class can change at anytime depend on the teachers handle the students; the teachers should be creative and flexible. Sometimes students can stop their activities more doing exercises, while their friend feel fed up, they were quite. These conditions only attended 15 minutes. Games would help students to add their vocabulary and games should relate with the material before. They were given exercises after explaining the material. 
Then, the students started doing the exercises. They were doing diligently and quickly. They are very confused but never give up doing their exercises. However, they could study English and do the exercises very quickly. It means that, the students were interested in English and accepted the lesson better. The teachers used fifteen minutes for answering the questions. After that, the questions would be discussed together. Then the teachers choose one the student for answer the question number one, the student gave right answer, but the second student gave wrong answer and the another student try to help their friend for answer of the question. It means that they have felt to help other students then they have fully spirit and never give up. These activities continued till all the questions done answered.

When the students finished their exercises, these exercises were corrected together. All questions would be answered together or written on the white board. From these exercises the writer gave a score. This score showed the ability of the students that they could understand the material or whether they were interested in the English lesson or not. Then, after 30 minutes, the student collect the exercise and this is exercise.

From all the explanation above, it shows that using games to teach is good technique especially by applying the creative activity one but there were also some disadvantages in using games in teaching question tags to the young learners especially for the sixth grade students in Butterfly English Course. The solution is the teachers should give some attractive games in every meeting so that they were not boring and paid attention to the teachers. Games will help the students for thinking that English is very fun and they would like with English lesson, the teacher should arrange the seat formation in semicircle in order to make easy with the students, sometimes they always made some problems. The solutions mentioned above probably not only help to handle the difficulties and problems that influence teaching process in the classroom, but also they are expected to minimize the problems. These solutions are useful for teachers to be applied in the classroom when they face the problem in teaching and learning process. 


\section{Sulistyawati, M. E. S., \& Warpindyastuti, L. D., Using Interactive...}

\section{CONCLUSION}

Teaching process is the facilitation of learning, in which the teacher can teach question tags using games. She knows a good method that can be used in teaching learning process. For teaching question tags, the teacher usually use media or tool for teaching such as game which can make students happy and excited to study question tags so they feel enjoy and fun while studying process. The teacher may need some extra equipment or materials to play the game and most of the time these equipment and materials are not available in the classroom.

Teaching is facilitation in learning process. Teaching is activity which is performed, directly or indirectly by human beings. Consequently, everyone who writes about it is a potential teacher or pupil and situation to show what the teacher explain to the pupils, that teaching is process of transferring and understanding from the teacher to the pupils. Teaching is not only giving lesson to the students but also how the teacher delivers the lesson to the student. Teaching can give the knowledge to the students and teaching can know the characteristic of the students.

Teaching English using games for students $6^{\text {th }}$ grade at Butterfly English Course can accept the lesson. The writer studies the material given assisted by books and guided by lesson plan is making. However, spirit preparation is certainly needed for avoiding anxiety when facing the students to deliver the lesson that games for children is facilitation and practice on one way in learning process which playing something by doing some fun activities. The writer using games for teaching question tags is suitable for this grade. The games are using to make the children easier to understand and remember the lesson in some topics. By using games, the children the students become active learners.

The writer finds the problems difficulties in teaching question tags using games. It is not easy for teaching the students. The writer has to be able to control the students and the teacher has be able to understanding the lesson and the games.. Difficulties in the learning process can be a challenge for a better teaching. Communication between teacher and the students have to be kept because communication is a media for making better results in the 
learning process if it is not miscommunication will be happened on communication between teacher and the students.

\section{Suggestion}

The writer has some suggestion for the teacher or the reader to read this paper. Firstly the writer teaching the students in English For All (EFA) English Course is not easy, because every student has different character. There is one who has attention with the lesson or who has behavior. So the teacher has to know how to control and handle the students. Then the teacher is able to make the students become more enthusiastic, interesting and enjoy the lesson so the students will not get bored. The teacher should try to be closer to the student, the teacher can be a good parents, friends and there is no limitation between the teacher and the students. The students feel comfortable in their class to the lesson.

In teaching learning activities the teacher has to be able to deliver the lesson easily, so that the student can understand the lesson from the teacher. Beside that the writer as the teacher should have a lot of vocabularies than the students. Therefore the writer has to study once more to teach question tags using games, the teacher can study from book and dictionaries.

Beside for the teacher, the writer also has suggestion for the 6th grade is not easy. The learners have to study hard and focus on the lesson in order to make the learners success in studying English. In this part the learners hope to be able to speaking, writing, reading and listening English as the target language. In teaching learning activity the learners have more attention of what the teacher explains about the lesson, the learners can ask the teacher. And the learners also do not make noisy and do not disturb each other friends who are studying in the class. Learning English is a little complicated. One must be able interesting and fun. In this paper, the writer gives suggestions for;

1. Teacher

They should be patient and understand the character of the students. For preventing boredom, a teacher can create games at the end of finish lesson. Teacher should choose their words to communicate to student students so that there is miscommunication and they will be able to clear instructions to the 


\section{Sulistyawati, M. E. S., \& Warpindyastuti, L. D., Using Interactive...}

students. Teacher must pay attention to students because not all students can students. Teacher must pay attention to students because not all students can communicate better. Do not give the most pressure or hardest to them because it is dangerous for their soul development.

\section{Reader}

Readers as a source of knowledge and can be a guide for readers who have problems when teaching students.

\section{Writer}

Writers as a next writer of final assignment must be given some knowledge to the readers and can be guide for readers who have problems when teaching students. And the writer must not be duplicated on his paper, add more references and using easy language for readers.

The suggestion above is based on the writer's teaching at English for All (EFA) English Course in Cirendeu, Tangerang Banten. Their writers hope that it can be useful for the readers who intend to teach question tags.

\section{REFERENCES}

Ersoz, A. (2000). Six Games for the EFL/ESL Classroom. Journal of TESL, 6.

Hong, L. (2002). Using Games in Teaching English to Young Learners. Journal of TESL, 8(8).

Gaudart, H. (1999). Games as Teaching Tools for Teaching English to Speakers of Other Languages. Journal of Simulation and Gaming, 30(22)

Huyen, N.T.T., \& Nga, K.T.T. (2003). Learning Vocabulary through games. Journal of Asian EFL

I-Jung. C, (2005). Using Games to Promote Communicative Skills in Language Learning. Journal of Internet TESL

Kim, L.S. (1995). Creative Games for the Language Class in English teaching Forum, (33)1

Kopecky, A. (2009). Using Games to Motivate your Adult ESL Students. Journal of ESL focus.

Kumar, R., \& Lightner, R. (2007) Games as an Interactive Classroom Technique. International Journal of Teaching and 
Learning in Higher Education, 19(1), 53-63

Mei, Y. Y. (2000). Using Games in an EFL Class for Children. Daejin University: ELT Research Paper.

Uberman, A. (1998). The Use of Games for Vocabulary Presentation and Revision in English Teaching Forum, 36(1).

Wright, A., Betteridge, D., \& Buckby, M. (1984). Games for Language Learning. Cambridge University Press.

Wishon, G., \& Julia, M. B., (1980). Let's Write English Revised Edition. New York: Litton Educational Publishing. 